\title{
Occurrence of the alien seagrass Halophila stipulacea in Martinique (French West Indies)
}

\author{
JEAN-PHILIPPE MARÉCHAL ${ }^{1,2}$, ERIK H. MEESTERS ${ }^{3}$, FABIEN VEDIE ${ }^{4}$ AND CLAIRE HELLIO ${ }^{2}$ \\ ${ }^{1}$ Observatoire du Milieu Marin Martiniquais, 14 rue Chery-Rosette, Fond Lahaye, 97233 Schœlcher, French West Indies, ${ }^{2}$ School of \\ Biological Sciences, King Henry Building, University of Portsmouth, Portsmouth, PO1 2DY, UK, ${ }^{3}$ Wageningen IMARES, Institute \\ for Marine Resources and Ecosystem Studies, Department of Ecosystems Den Burg, The Netherlands, ${ }^{4}$ Direction de \\ l'Environnement, de l'Aménagement et du Logement, BP 7212, 97233 Schœlcher, French West Indies
}

\begin{abstract}
The occurrence of the tropical seagrass Halophila stipulacea (Hydrocharitaceae) is recorded for the first time on the Caribbean coast of Martinique (French West Indies, Caribbean Sea). Specimens were observed, since a large survey in 2006, on sandy substrates between $3 \mathrm{~m}$ and $32 \mathrm{~m}$ depths in this area. The species was found in mono-specific patches or mixed with other macrophytes as Syringodium filiforme (seagrass) and/or Ulva intestinalis (green alga). Halophila stipulacea was previously identified on the coasts of Dominica and St Lucia, two islands nearby our study area. While its presence was presumed to be in Martinique, it was never officially recorded. These findings off the coast of Martinique further define the distribution and widespread occurrence of this alien species within the Caribbean Sea.
\end{abstract}

Keywords: allochthonous species, Caribbean Sea, Halophila stipulacea, marine angiosperms, Martinique, West Indies

Submitted 11 March 2013; accepted 22 October 2013

\section{INTRロDUCTIDN}

Marine alien invasive species are recognized as one of the largest threats to global marine biodiversity (Molnar et al., 2008). Most alien species are introduced by either ballast water (microorganisms, microalgae and marine plants), hullfouling (macroalgae and invertebrates) (Gollasch et al., 2000; Gollasch, 2002; Minchin et al., 2009) or shellfish translocation (Minchin, 2007). If alien species are able to adapt to new environmental conditions and reproduce, they can compete with native species and change ecosystem processes by upsetting the natural community balance (Anil et al., 2002; Occhipinti-Ambrogi \& Savini, 2003; Occhipinti-Ambrogi, 2007; Naršcius et al., 2012). A poignant example where this has happened is the invasion of the Mediterranean by the tropical seagrass Halophila stipulacea (Forsskål) Ascherson (Hydrocharitacea) from the Red Sea after the opening of the Suez Canal, probably mediated by boat traffic (Ruiz \& Ballantine, 2004; Gambi et al., 2009), but likely carried on-board small vessels, attached to fishing gear and released in new habitats (Lipkin, 1975). In the Mediterranean environments $H$. stipulacea meadows induced changes in the subtidal communities (Di Martino et al., 2006). A comparison between the associated algal assemblages of an invaded meadow with two contiguous meadows, dominated respectively by the seagrasses Posidonia oceanica (L.) Delile and Cymodocea nodosa (Ucria) Ascherson, revealed significant differences in species

Corresponding author:

J.-P. Maréchal

Email: marechal.jean@gmail.com composition in the invaded community (Di Martino et al., 2006). Halophila stipulacea was discovered in the western Atlantic off the island of Grenada in 2002, and it is believed to have originated from the Mediterranean (Ruiz \& Ballantine, 2004; Ruiz et al., 2009). Since that record, the species has been documented in St Lucia and Dominica in 2009 (Willette \& Ambrose, 2009) and significant evidence has shown $H$ stipulacea displacing native Caribbean seagrasses (Willette \& Ambrose, 2012).

The global distribution of seagrass species is divided within 6 geographical bioregions (Temperate North Atlantic, Tropical Atlantic, Mediterranean, Temperate North Atlantic, Tropical Indo-Pacific and Temperate Southern Oceans) based on assemblages of taxonomic groups (Short et al., 2001, 2007). The Tropical Atlantic (including the Caribbean Sea, Gulf of Mexico, Bermuda, the Bahamas, and both tropical coasts of the Atlantic) harbour a high diversity of tropical seagrasses with native species (Halodule beaudettei den Hartog, Halodule wrightii Ascherson, Halodule bermudensis den Hartog, Halophila baillonii Ascherson, Halophila decipiens Ostenfeld, Halophila engelmanni Ascherson, Halophila johnsonii Eiseman, Ruppia maritima Linnaeus, Syringodium filiforme Kützing and Thalassia testudinum Banks) and one introduced species (Halophila stipulacea) growing on back reefs and shallow banks in clear water (Short et al., 2001, 2007). Among all the seagrass species worldwide, four species have been introduced outside their native range: $H$. stipulacea; $H$. decipiens Ostenfeld; Zostera tasmanica Martens; and Z. japonica Ascherson \& Graebner (Williams, 2007). The colonization success of $H$. stipulacea has been linked to its efficient dispersal mechanisms via currents, and to its rapid vegetative expansion (Marba \& Duarte, 1998; 
Williams, 2007; Willette \& Ambrose, 2009). Boudouresque \& Verlaque (2002) observed that $H$. stipulacea has a similar growth rate and occurrence of the invasive macrophyte Caulerpa taxifolia (M.Vahl) C. Agardh. Halophila stipulacea can be found at various depths (from intertidal to $>_{50} \mathrm{~m}$ ) and it can tolerate great variations in salinity as well as high level of irradiance (Por, 1971; Beer \& Waisel, 1981; Schwarz \& Hellblom, 2002; Willette \& Ambrose, 2009).

The Martinique coastal communities have been extensively surveyed during the last 10 years (Legrand et al., 2012), and a species of the genus Halophila was noted during a marine habitat mapping survey in 2006. This paper reports the occurrence of Halophila stipulacea on the Caribbean coast of Martinique, documenting its rapid spread in the Caribbean Sea from its first record in Grenada in 2002 (Ruiz \& Ballantine, 2004).

\section{MATERIALS AND METHDDS}

\section{Marine habitats and life forms mapping data from 2006 in Martinique coastal waters}

The sampling effort of Martinique coastal communities has increased in the last decade. The authors have obtained extensive data on seaweed and seagrasses biodiversity, abundance and distribution for this particular area since the commencement of monitoring studies. Bi-annual coral reef monitoring programmes were undertaken from 2001, as part of the French Coral Reef Initiative programme (IFRECOR) and habitat mapping of marine ecosystems was initiated in 2006, covering an area of over $450 \mathrm{~km}^{2}$ to a depth of $50 \mathrm{~m}$ around the island (Legrand et al., 2012). A total surface area of $49.74 \mathrm{~km}^{2}$ was mapped for seagrass communities; $94 \%$ of these were present between $10 \mathrm{~m}$ depth and the surface, while the majority comprised Syringodium filiforme, Thalassia testudinum or mixed beds of different seagrass species. During the survey, a taxon was recorded at this time and attributed to the genus Halophila, but not identified at the species level (OMMM (Observatoire du Milieu Marin Martiniquais) GIS database).

\section{Halophila stipulacea identification}

The specimens collected in Martinique were carefully identified according to morphological characters detailed in den Hartog (1970) and Kuo \& den Hartog (2011): wideness of the rhizome ( 0.5 to $2 \mathrm{~mm}$ ), size of the leaf blades ( 3 to $6 \mathrm{~cm}$ long and 2.5 to $8 \mathrm{~mm}$ wide) and morphological features (dioecious specimens; margin serrulate; apex obtuse; base cuneate or gradually decurrent-petiolate; cross veins ascending at 45-6o degrees; petiole $0.5-1.5 \mathrm{~cm}$ long, sheathing lopsidedly at base) and ecological features such as the habitat (subtidal sandy and muddy bottoms, intertidal, sheltered localities).

\section{Halophila stipulacea survey in 2010}

Once the presence of Halophila stipulacea was confirmed, a sampling programme was organized in 2010 to assess the range and magnitude of its distribution off the north Caribbean coast of Martinique, between the north of Fort de France Bay and the north bay of Saint Pierre (Figure 1). The area sampled for $H$. stipulacea occurrence represented $22 \mathrm{~km}$ of coastline and covered about $9.26 \mathrm{~km}^{2}$. Communities' surface areas from the 2006 mapping campaign were estimated as: algal communities $=0.68 \mathrm{~km}^{2}$; coral reefs $=0.77 \mathrm{~km}^{2}$; infauna/sand $=5.55 \mathrm{~km}^{2}$; and seagrasses $=$ $2.26 \mathrm{~km}^{2}$.

A small vessel was used in March 2010 to collect the data and samples. Sampling transects perpendicular to the coast, at depths between 3 and $32 \mathrm{~m}$ (two points) were chosen to check for seagrass communities. A drop-video recording system was used to record the sea bottom at each location. This system consisted of a waterproof CCTV camera, equipped with LEDs fixed to a steal platform, connected to a digital video recorder and screen through a $50 \mathrm{~m}$ video cable, and it allowed real time visual identification of specimens as well as file recording (about 15 seconds). The video system used was identical to the one used during the 2006 habitat mapping campaign. Each record was used to describe the nature of the bottom in terms of the seagrass species that were observed. The records were transferred to an Excel file with sampling points as lines and columns with geographical coordinates, species identification and substrate identification for year 2006 and year 2010. Ninety videos were recorded. Each site was geo-referenced (Garmin GPS) and data were used in a GIS database to produce maps of visual Halophila stipulacea occurrence off the Caribbean coast of Martinique.

Of the 90 records obtained from 2010, 67 were compared to 2006 records as to whether they matched geographical coordinates area (there was no connection to past data for the other 23). The videos from the 2006 marine habitatmapping project were re-examined to check for Halophila stipulacea presence. This permitted a comparison of the sea bottom (benthic communities' features, presence/absence of $H$. stipulacea and other species) in terms of species occurrence and cover changes vs time to be performed (Table 1 ). A Chi-squared test ( $\chi^{2}$ in $\mathrm{R}$-software for statistical computing and graphics, version 3.0.2) was performed to highlight significant changes in the benthic communities' cover between the two surveys. To calculate percentage changes over time, the following coding system for each record was used: no changes or unidentified records were coded as o; changes to $H$. stipulacea seagrass beds were coded as 1 ; and changes to other seagrass species (different from $H$. stipulacea) were recorded as 2. The percentage change was calculated as the percentage of $H$. stipulacea seagrass beds over the total of sea bottom community changes.

\section{RESULTS AND DISCUSSION}

A first identification of specimens filmed in 2006 and attributed to the alien species Halophila stipulacea was made in 2010. A small patch $\left(>_{1} \mathrm{~m}^{2}\right)$ of Halophila was checked at Anse Madame $\left(14^{\circ} 37^{\prime} \cdot 38^{\prime \prime} \mathrm{N} 61^{\circ} 6^{\prime} 19.23^{\prime \prime} \mathrm{W}\right)$ early 2010 , at $11 \mathrm{~m}$ depth (Figure 1) and identified as H. stipulacea. Several specimens from this first collection were preserved dry in a herbarium for reference at OMMM.

In April 2010 additional patches of Halophila stipulacea were observed along the Caribbean coast of Martinique, from the Fort de France Bay to the northern bay of St Pierre (Figure 1). This survey provided valuable information on the distribution and habitat of $H$. stipulacea. Specimens were detected at depth from 3 to $32 \mathrm{~m}$, on sandy substratum, 


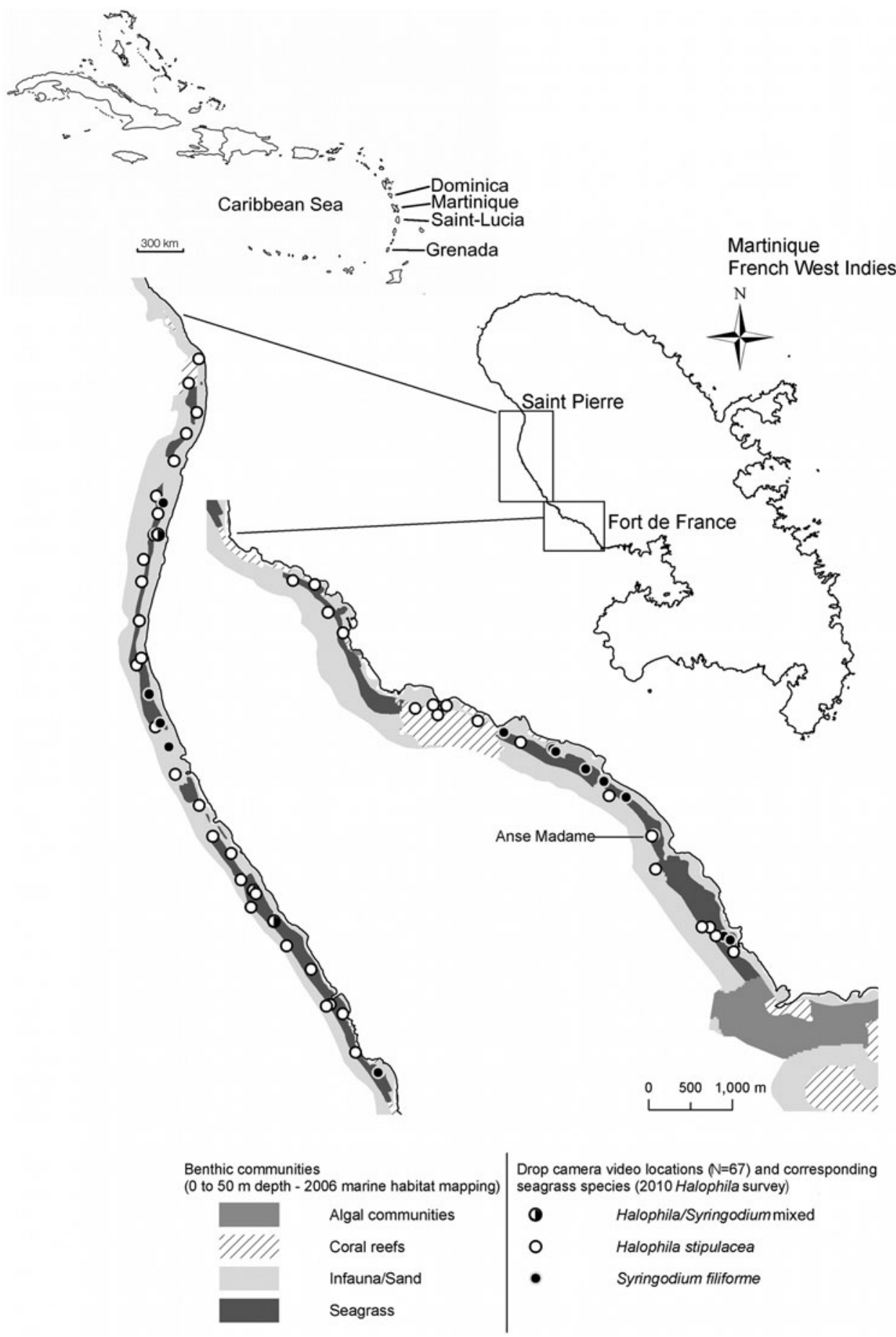

Fig. 1. Marine habitats (2006 data) and geographical distribution of Halophila stipulacea along the Caribbean coast of Martinique (2010 data), French West Indies.

always in sheltered areas and regularly dispersed along the coast. Most of the H. stipulacea patches observed were dense and monospecific. However, some mixed-patches were detected, which were composed of $H$. stipulacea and Ulva intestinalis, $H$. stipulacea and S. filiforme, or H. stipulacea and cyanophycean (undetermined species covering the seagrass canopy).

Recordings made during the Martinique survey of 2010 occurred all along the north Caribbean coast, suggesting that $H$. stipulacea had widely extended since 2006 (10s of $\mathrm{km}$ along the coast). The occurrence of $H$. stipulacea in
Martinique might possibly be linked to maritime transportation in the Lesser Antilles and its dispersal could be associated with the intense tourist sailing activity in the region (Ruiz \& Ballantine, 2004; Galil, 2006; Willette \& Ambrose, 2009). As a general trend, the initial occurrence of $H$. stipulacea in a new geographical area is often located in the close vicinity of ports or anchorage areas as previously reported in the Mediterranean (Greece, Malta, Sicily and Tunisia) and Caribbean Seas (Grenada, Dominica and St Lucia) (Ruiz \& Ballantine, 2004; Gambi et al., 2009; Willette \& Ambrose, 2009). 
Table 1. Comparison of benthic community changes between 2006 and 2010 along the Caribbean coast of Martinique (French West Indies) and coding system for percentage change calculation. Data were obtained from video recordings $(\mathrm{N}=67)$.

\begin{tabular}{|c|c|c|c|c|c|}
\hline \multirow[b]{2}{*}{ Benthic community types } & \multicolumn{2}{|l|}{ Years } & \multicolumn{3}{|l|}{ Coding system } \\
\hline & 2006 & 2010 & Unchanged/undetermined & New Halophila stipulacea & New Syringodium filiforme \\
\hline Degraded patch reef & 4 & o & - & 4 & - \\
\hline Infauna & 28 & o & - & 26 & 2 \\
\hline Seagrass & 14 & o & 14 & - & - \\
\hline Seagrass H. stipulacea & 10 & 46 & 7 & - & 3 \\
\hline Seagrass partches $H$. stipulacea & 6 & 4 & 1 & 5 & - \\
\hline Seagrass patches $S$. filiforme & 5 & 17 & 1 & 4 & - \\
\hline Total & 67 & 67 & 23 & 39 & 5 \\
\hline
\end{tabular}

Once the presence of Halophila stipulacea in the coastal waters of Martinique had been confirmed in 2010, the species showed a wide distribution, extending from the north at St Pierre Bay to the south at Fort de France (Figure 1). The main threat is that H. stipulacea could potentially out-compete native seagrasses inducing changes in the subtidal community structures as surveys show changes at several previous Syringodium filiforme locations in favour of $H$. stipulacea. However, the influence of $H$. stipulacea might not be that great because its small size could allow it to co-exist under canopies of the larger native seagrass species (such as Thalassia or Syringodium) and has been shown in mixed meadows already documented in the study area. For this reason, the impact of this alien species on the abundance of other seagrass species is difficult to predict (Williams, 2007).

Nonetheless, our initial surveys indicate that community structure changes have taken place since the introduction of Halophila stipulacea, like in the Mediterranean as mentioned by Di Martino et al. (2006). Changes in the seabed composition were noted when the results from the 2010 survey were compared to the 2006 data. Changes in the benthic communities accounted for $65.7 \%$ compared to 2006 . While $34.3 \%$ was unchanged, $58.2 \%$ was due to new $H$. stipulacea area and $7.46 \%$ was new Syringodium filiforme settlement. Among the percentage changes observed, this represents $88.6 \%$ in favour of the alien species $H$. stipulacea, indicating its high spreading capacities. A Chi-squared test, assuming similar distribution of seagrasses and other categories stated that both $S$. filiforme and $H$. stipulacea occurrence increased, the latter much more, while the other categories have disappeared $\left(\chi^{2}=78.59, \mathrm{df}=5, P<0.001\right)$. Our data testify to the high spreading capacity of $H$. stipulacea in new available environment, like sandy areas, as well as in previously colonized areas of other seagrass species, showing a substitution of indigenous phanerogam species within four years. Seagrass dynamic is highly subjected to coastal development and stochastic environmental events. It is then important to increase monitoring of these coastal ecosystems as community changes can occur very rapidly. Continuous effort is also required to assess the impact of $H$. stipulacea on usual seagrass benthic associated communities.

\section{ACKNDWLEDGEMENTS}

The authors thank the 'Direction de l'Environnement, de l'Aménagement et du Logement Martinique (DEAL)' for funding the sampling campaign and Dr Julian Mitchell
(University of Portsmouth) for his advice during the preparation of this manuscript.

\section{REFERENCES}

Anil A.C., Venkat K., Sawant S.S., Dileepkumar M., Dhargalkar V.K., Ramaiah N., Harkantra S.N. and Ansari Z.A. (2002) Marine bioinvasion: concern for ecology and shipping. Current Science 83, 214-218.

Beer S. and Waisel Y. (1981) Effects of light and pressure on photosynthesis in two seagrasses. Aquatic Botany 13, 331-337.

Boudouresque C.F. and Verlaque M. (2002) Biological pollution in the Mediterranean Sea: invasive versus introduced macrophytes. Marine Pollution Bulletin 44, 32-38.

den Hartog C. (1970) The sea-grasses of the world. Verhandelingen der Koninklijke Nederlandse Akademie van Wetenschappen, Afdeling Natuurkunde, Tweede Reeks 59, 1-6.

Di Martino V., Blundo M.C. and Tita G. (2006) The Mediterranean introduced seagrass Halophila stipulacea in eastern Sicily (Italy): temporal variation of the associated algal assemblage. Vie et Milieu 56, 223-230.

Galil B.S. (2006) Species factsheet: Halophila stipulacea. In Delivering Alien Invasive Species Inventories for Europe (DAISIE). Available at: http://www.europe-aliens.org (accessed 5 November 2006).

Gambi M.C., Barbieri F. and Bianchi N. (2009) New records of the alien seagrass Halophila stipulacea (Hydrocharitaceae) in the western Mediterranean: a further clue to changing Mediterranean Sea biogeography. Marine Biodiversity Records e84, 1-7. doi: http://dx.doi.org/

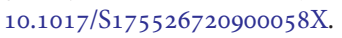

Gollasch S. (2002) The importance of ship hull fouling as a vector of species introductions to the North Sea. Biofouling 18, 105-121.

Gollasch S., Lenz J., Dammer M. and Andres G. (2000) Survival of tropical ballast water organisms during a cruise from the Indian Ocean to the North Sea. Journal of Plankton Research 22, 923-937.

Kuo J. and den Hartog C. (2011) Seagrass taxonomy and identification key. In Short F.T. and Coles R.G. (eds) Global seagrass methods. Amsterdam: Elsevier Sciences B.V., pp. 31-58.

Legrand H., Lenfant P., Sotheran I.S., Foster-Smith R.L., Galzin R. and Maréchal J.P. (2012) Mapping marine benthic habitats in Martinique (French West Indies). Caribbean Journal of Science 46, 267-282.

Lipkin Y. (1975) Halophila stipulacea, a review of a successful immigration. Aquatic Botany 1, 203-215.

Marba N. and Duarte C.M. (1998) Rhizome elongation and seagrass clonal growth. Marine Ecology Progress Series 174, 269-280. 
Minchin D. (2007) Aquaculture and transport in a changing environment: overlap and links in the spread of alien biota. Marine Pollution Bulletin 55, 302-313.

Minchin D., Gollasch S., Cohen A.N., Hewitt C.L. and Olenin S. (2009) Characterizing vectors of marine invasion. Ecological Studies 204, $109-1166$.

Molnar J.L., Gamboa R.L., Revenga C. and Spalding M.D. (2008) Assessing the global threat of invasive species to marine biodiversity. Frontiers in Ecology and the Environment 6, 485-492. doi:10.1890/ 070064 .

Narščius A., Olenin S., Zaiko A. and Minchin D. (2012) Biological invasion impact assessment system: from idea to implementation. Ecological Informatics 7, 46-51.

Occhipinti-Ambrogi A. (2007) Global change and marine communities: alien species and climate change. Marine Pollution Bulletin 55, 342352.

Occhipinti-Ambrogi A. and Savini D. (2003) Biological invasions as a component of global change in stressed marine ecosystems. Marine Pollution Bulletin 46, 542-551.

Por F.D. (1971) One hundred years of Suez Canal-a century of Lessapian migration: retrospect and viewpoints. Systematic Zoology 20, 138-159.

Ruiz H. and Ballantine D.L. (2004) Occurrence of the seagrass Halophila stipulacea in the tropical west Atlantic. Bulletin of Marine Science 75, $131-135$.

Ruiz J.M., Boudouresque C.F. and Enriquez S. (2009) Mediterranean seagrasses. Botanica Marina 52, 369-381.
Schwarz A.M. and Hellblom F. (2002) The photosynthetic light response of Halophila stipulacea growing along a depth gradient in the Gulf of Aqaba, the Red Sea. Aquatic Botany 74, 263-272.

Short F.T., Coles R.G. and Pergent-Martini C. (2001) Global seagrass distribution. In Short F.T. and Coles R.G. (eds) Global seagrass methods. Amsterdam: Elsevier Sciences B.V., pp. 5-30.

Short F., Carruthers T., Dennison W. and Waycott M. (2007) Global seagrass distribution and diversity: a biogeographical model. Journal of Experimental Marine Biology and Ecology 350, 3-20.

Willette D.A. and Ambrose D.F. (2009) The distribution and expansion of the invasive seagrass Halophila stipulacea in Dominica, West Indies, with a preliminary report from St Lucia. Aquatic Botany 91, 137-142.

Willette D.A. and Ambrose D.F. (2012) Effects of the invasive seagrass Halophila stipulacea on the native seagrass, Syringodium filiforme, and associated fish and epibiota communities in the Eastern Caribbean. Aquatic Botany 103, 74-82.

and

Williams S.L. (2007) Introduced species in seagrass ecosystems: status and concerns. Journal of Experimental Marine Biology and Ecology $350,89-110$

\section{Correspondence should be addressed to:}

J.-P. Maréchal

Observatoire du Milieu Marin Martiniquais

14 rue Chery-Rosette, Fond Lahaye, 97233 Schœlcher,

French West Indies

email: marechal.jean@gmail.com 